\title{
BOGANMELDELSER
}

Henriks Stevnsborg: Politi 1682-2007. Samfundslitteratur, København 2010. (225 s.)

Å la en norsk jurist skrive anmeldelse av en dansk historikers bok om interne danske forhold, er et vågelig foretakende. Med et slikt utgangspunkt ligger det $\mathrm{i}$ sakens natur at anmeldelsen $\mathrm{i}$ betydelig grad vil få et komparativt preg.

Boken spenner over en tidsperiode på 325 år, og tar en bort innholdsfortegnelse og registre, gjøres dette på vel 200 sider inklusive en del illustrasjoner. Det sier seg selv at innenfor slike rammer blir det i liten grad mulighet for "dypdykk". Forfatterens siktemål med boken har vært å skrive en komprimert lærebok i politihistorie for studentene ved den danske politiskolen. Av denne grunn har han vært nødt til å holde seg til hovedlinjene i utviklingen, men har kompensert for dette på to måter: Etter hvert kapittel i boken er det en til dels omfattende litteratur- og kildeliste for de som ønsker å fordype seg ytterligere i emnet. I de fleste kapitler behandles også enkelte temaer noe mer omfattende i kompress. Jeg synes boken gir en god og instruktiv beskrivelse av hvordan dansk politiet har utviklet seg. Uten spesielle forkunnskaper, sitter jeg, etter å ha lest boken igjen med et klart inntrykk av hvordan dansk politi har vokst frem fra den ene mann i med to oppgaver i København i 1682 til et korps på vel 14000 tjenestepersoner som i dag er beskjeftiget med oppgaver også langt utenfor Danmarks grenser.

Boken omhandler perioden fra 1682 til 2007 da den siste av politireformene i Danmark trådte i kraft. I et forholdsvis omfattende forord gis vi likevel et visst innblikk i viktige utviklingstrekk også etter 2007. Boken består i tillegg til forordet av 14 kapitler. De første fire kapitlene tar for seg tiden fram til ca. 1900, mens de resterende er viet utviklingen og markante hendeler de siste ca. 100 år. Boken inneholder ikke noe stikkordsregister, men en omfattende innholdsfortegnelse på nesten fire sider kompenserer i en viss grad for dette.

Forfattere av fagbøker må ofte foreta vanskelige valg om hva som skal være det styrende parameter for disposisjonen. For historiske fremstillinger står valget ofte mellom "tid" eller "tema". Stevnsborg har valgt "tid", dvs. at de ulike hendelser og utviklingstrekk beskrives kronologisk slik de skjedde i tiden som samvirkende, motvirkende eller helt uavhengige hendelser. Med "tema" som styrende parameter hadde det for eksempel vært naturlig med en inndeling basert på hvordan organiseringen av politiet, ordenstjenesten, etterforskingsvirksomheten, rekrutteringen m.v. har endret og utviklet seg i perioden. Når jeg skal vurdere forfatterens valg, er det en ulempe å være norsk. Det er åpenbart lettere å følge og forstå en fremstilling basert på tidslinjen hvis man er fortrolig med de sentrale trekk og skjellsettende begivenheter i dansk samfunnsutvikling, slik man må forvente av 
den jevne danske politistudent er. Tross dette, for den vedvarende kamp mellom sentraliserende og desentraliserende krefter, mener jeg fremstillingen ville ha tjent på, i alle fall en tematisk oppsummering av utviklingen i 300-års-perioden.

Jeg vil i denne anmeldelsen trekke frem tre temaer: Det første har jeg allerede nevnte, nemlig den vedvarende, og for meg overraskende kamp, for å beholde en sterkt desentralisert politistruktur. De to andre er mer isolerte hendelser: Politiets rolle og virke under okkupasjonen i 1940-45, og Nørrebro-urolighetene i 1993.

Fra årtusenskiftet ble antall politidistrikter i Norge redusert fra 54 politidistrikter 27. I debatten omkring den norske organisasjonen var det egnet til å overraske at også Danmark på dette tidspunkt hadde 54 distrikter. Forklaringen synes å begynne vel 300 år tilbake. Den første dedikerte politimann ble ansatt i København i 1682. Allerede knappe 10 år senere kom den første - lille - politiforordning, som i 1701 ble avløst av den store politiforordning. Dette var bestemmelser om hva politiet skulle gjøre. De gjaldt for hele landet, men var skrevet i København og for forholdene som hersket der i byen, jf. bokens to første kapitler som omfatter 16- og 1700-tallet. Å gjøre forordningen gjeldende for resten av landet som verken hadde noen egentlig politistyrke og heller ikke hadde de samme problemer som København, måtte i alle fall legge kimen til at sentralt styrt politivirksomhet kom i miskreditt. På landet skulle politioppgavene ennå lenge bli en del av den dømmende makts mange oppgaver. Det var ennå ca 150 år igjen til maktfordelingsprinsippet formelt ble innført i Danmark (1849, jf. kap. 3) og vel 200 år til det reelt var gjennomført ved at den utøvende og dømmende makt skilte lag, (1919, jf. retsplejereformen omhandlet i bokens kap. 5). Det hjalp selvsagt heller ikke på anseelsen til en sterk og sentralt styrt politimakt at politiet ennå i en periode på innpå to hundre år i stor utstrekning var et lydig redskap for den eneveldige kongemakten.

Politivesenet i utenfor København ble foreslått reformert midt på 1800-tallet med 46 selvstendige politikretser under ledelse av en politimester. Iflg. Stevnsborg falt forslaget på finansieringen, og i 1871 ble det besluttet å opptrettholde ordningen med at polititjenesten i provinsen fremdeles skulle dekkes av rettsbetjentene og deres underordnet i til sammen vel 150 kretser! Selv om retsbetjentene ved reformen i 1919 ble omgjort til politimestre som polisiær og påtalemessig leder av virksomheten i sin politikrets og antallet ble redusert til 65 utenfor København, viser Stevnborgs at de små kretsene verken ordensmessig eller etterforskingsmessig kunne dekke behovet for polisiære tjenester.

I kap. 4 (Gendarmene) og 5 (Statspolitiet) beskrives hvordan denne utilstrekkelige politidekning ble møtte med mottiltak. Tidlig ut på 1900-tallet var et sentralt statspoliti etablert, men dette skulle bare bistå det de lokale enheter, og være underlagt den lokale politimesteren under bistandsarbeidet. Til tross for at statspo- 
litiets bistandsenheter raskt viste seg eksistensberettiget og effektive, var motstanden mot dem betydelige. En av årsakene var at organiseringen av politiet var blitt en partipolitisk kampsak etter at Danmark ble et demokrati med parlamentarisme. I perioder hvor partiet Venstre satt med makten var det vanskelig for å vinne gehør for et sentralt styrt enhetspoliti. Det ble likevel i 1925 nedsatt en Politikommisjon til bl.a. å se på organiseringen av politiet, og kommisjonens flertall foreslo i 1926 at ordningen med et kommunalt finansiert ordenspoliti og et statlig kriminalpoliti, ble erstattet av et enhetspoliti under overordnet sentral ledelse av et direktorat, jf. kap. 6. Før forslaget ble behandlet politisk hadde imidlertid Venstre igjen overtatt regjerningsmakten og statspolitiets sterke leder hadde dessuten dødd. Selv om det nasjonalt lå til rette for en ytterligere sementering av den desentraliserte struktur, viser Stevnsborg hvordan dette ble motvirket av frykten for en kommunistisk statskupp og disposisjonene til den nazistisk styrte nabo i sør.

I bokens kap. 9 beskriver Stevnsborg politiet under den kalde krigen. Frykten for hva som var Det danske Kommunistpartiets (DKP) planer, ledet rett etter krigen til en sterk sentral og regional ledelse av det danske politiet. Men allerede i 1946 ble faren for udemokratiske aksjoner fra DKP avblåst, og man gikk tilbake til en ledelse basert på 72 politidistrikter. En mer sentralt forankret ledelse hadde lite vind i seilene. Den kalde krig, jernteppet og frykten for at Sovjetunionens innflytelsessfære skulle strekke seg lenger enn til de baltiske stater, Øst-Tyskland og Tsjekkoslovakia, gjorde imidlertid at ytterligere nedbygging av politiets sentrale ledelse ikke fikk gjennomslag.

Kapittel 10 i boken er viet politireformen i 1973. På 1960 tallet hadde Danmark 1386 kommuner (!!), 24 fylker (amt) og 72 politidistrikter. I 1970 kom den store kommunereformen som reduserte kommuneantallet til 277 og fylkene til 14. Og nå sto selvsagt politiet for tur. Ved politireformen i 1973 forsøkte man å basere inndelingen på samme lest som kommunereformen, nemlig slik at hvert politidistrikt burde dekke et større bysamfunn og området rundt, og dessuten ha en slik størrelse at 5 tjenestepersoner kunne være på vakt 24/7. Ut fra størrelsen på datidens politikorps skulle dette tilsi en halvering til 35 politidistrikter. Etter protester og tautrekking endte man med de 54 som eksisterte da denne anmelder begynte å interessere seg for politiet. Stevnsborgs viser her at vi nå kommet inn i tidsperioden hvor kravet om effektivitet melder seg med full styrke også for offentlige virksomhet. Bare vel 20 år etter reformen i 1973 nedsettes derfor en ny kommisjon til å "endevende" politiets virksomhet og organisering, jf. bokens kapittel 12. Det viktigste som kom ut av kommisjonens arbeid var et forslag til en ny materiell politilov for dansk politi, vedtatt i 2004, jf. bokens side 189-90. Om strukturen hadde Politikommisjonen fătt bundet mandat: Antall politidistrikter skulle ned, og kommisjonen foreslo da også en halvering til 25 og en generell styrking og 
reduksjon av antall regioner. Forslaget ble aldri realitetsbehandlet, men kort tid etter nedsettes "Vidsjonsudvalget", jf. kap. 13. Og nå er det ikke lenger antallet distrikter (eller kretser) som avgjørende, men at de lokale kretser er bæredyktige. Dette ledet fram til reformen i 2007 hvor kretsene ble redusert til 12, altså bare halvparten av de 25 som få år tidligere var ansett som et radikalt forslag.

Bokens kap. 7 og 8 handler om dansk politi under den tyske okkupasjonen og rettsoppgjøret etter krigen. Av de nordiske landene er det først og fremst Danmark og Norge hvor politiet ble stilt overfor de utfordringer som en okkupasjon innebærer. Stevnsborgs beskrivelse av dansk politi under den tyske besettelsen, ga meg ny kunnskap og grunnlag for ny refleksjon om det norske politiets stilling under krigen. Mens danskene var levnet lite annet valg enn å samarbeide med okkupasjonsmakten, kunne Norge velge den motsatte linje. For norske polititjenestemenn innebar dette et vanskelig valg allerede fra okkupasjonens første dager: Skulle de bli i tjenesten og dermed bli okkupasjonsmaktens sivile maktapparat? Dette var et valg som dansk politi ikke ble stilt ovenfor. De forholdt seg fremdeles til sin ordinære ledelse. Selv om begge lands politikorps jevnlig ble stilt overfor vanskelige valg, må på den annen side de "daglige" alternativene langt på vei ha vært tydeligere for de norske politifolkene: Det var okkupasjonsmakten som bestemte og kunne ikke forvente noen større grad av lydighet. På den annen side kunne politiet påregne anerkjennelse både fra befolkningen og fra de lovlige myndigheter i eksil, for tjenesteutøvelse som vanskeliggjorde eller saboterte tyske beslutninger. For dansk politi må situasjonen ha vært mer uklar. De tjente fremdeles sin Konge og regjering og skulle vise lydighet mot disse, men hvordan skulle dette påvirkes av at de regjerte på okkupasjonsmaktens nåde? Hvor går grensen mellom tjenesteplikt og overivrighet i en slik situasjon?

Et av de mørkeste kapitler i norsk politis okkupasjonshistorie, er dets medvirkning til deportasjon av norske jøder. For dansk politi forteller Stevnborgs okkpasjonskapittel om en annen skamplett. Etter at Tyskland hadde brutt ikkeangrepsavtalen med Sovjet, fremsatte tyskerne ønsket om arrestasjon og internering av ledende danske kommunister. Stevnsborg fremholder her at dansk politi gikk lenger enn okkupasjonsmakten uttrykkelig hadde anmodet om, og kanskje også lenger enn det de ville ha akseptert. Arrestasjonene 22. juni 1941 må trolig sees på bakgrunn av to forhold: Dels at orderen til politiet ble formidlet av de ordinære danske foresatte som stryken følte en naturlig lojalitet ovenfor, og dels av at dansk politi på 1930-tallet - iflg. Stevnsborg med en viss grunn - hadde fryktet udemokratiske sabotasjehandlinger fra danske kommunister. Uansett årsak, kommunistinterneringen var en handling dansk politi fikk betale ganske dyrt for i form av svekket anseelse i mange år etter krigen.

Nørrebro-hendelsen 18. mai 1993 (kap. 11) har jeg valgt ut fordi den viser 
at omdømmebelastningen for politiet ikke bare henger sammen med størrelsen eller antallet av de feildisponeringer som gjøres under en politioperasjon, men påvirkes ofte vel så mye av hvordan hendelsen håndteres og kommenteres i ettertid. Personlig tror jeg Stevnsborg gjennom sin beskrivelse av hvordan Nørrebrourolighetene ble håndtert i ettertid, rører ved en mer grunnleggende svakhet ved politikulturen. Både som etat og som enkeltindivider synes politiets selvfølelse å være knyttet til at de ikke gjør feil. Dette til tross for at de opererer i situasjoner hvor det på løpende bånd og umiddelbart må treffes avgjørelser i opphissede situasjoner hvor det ikke på noen måte er mulig å ha oversikt over alle fakta. Jeg tror både de involverte og befolkningen vil ha stor forståelse for at man i slike situasjoner kan komme til å gripe feil. Men skaden forsterkes i alle fall hvis man $\mathrm{i}$ ettertid søker å begrunne at handlingene likevel var korrekte og hensiktsmessige! De temaer jeg har valgt ut til en særlig omtale, yter selvsagt ikke boken POLITI 1682-2007 noen full rettferdighet. Man finner også behandling av hvordan dansk politi opp gjennom tidene har samarbeidet med og dels basert seg på den militære makt, svingt mellom proaktiv og reaktiv polititjeneste, kvinnenes inntreden i politiet, utviklingen i politiutdannelsen, hvordan dansk politi nå er engasjert i internasjonale oppdrag, og meget mer.

I den grad denne anmelder bedriver noen form for organisert idrett, består det i roing, hvor man sitter med ryggen i fartsretningen og det er blikket for hvor man kommer fra som viser kursen. Slik sett burde roing være historikernes idrett framfor noe. Gjennom boken "POLITI 1682-2007" har Henrik Stevnborg gitt oss sikre og tydelige navigeringspunkter både i fjern og nær fortid, som vil være et godt og verdifullt hjelpemiddel når den polisiære kursen skal settes mot den usikre fremtid!

\section{Tor-Geir Myhrer}

Politihøgskolen i Oslo

Ragnar Hauge: Rus och rusmidler gjennom tidene. Universitetsforlaget, Oslo 2009.

Jag är enig med Ragnar Hauge, när han i förordet till sin bok skriver att "det er selfølgelig umulig å gi en fyllestgjørende beskrivelse av broken av ulike rusmidler i et historisk perspektiv”. Det är ändå något som Hauge försöker att göra på 234 sidor i denna bok - och han är inte den första som gör det. Man kan nämna till exempel Wolfgang Schivelbusch's klassiker "Paradiset, smaken och förnuftet: njutningsmedlens historia" (original från 1980 Das Paradies, der Geschmack und die Vernunft : eine Geschichte der Genussmittel) eller David T. Courtwright's Vanansmakt. Drogernas historia och den moderna världens födelse (original Forces 
of Habit: Drugs and the Making of the Modern World från 2001). Skillnaden mellan de två ovannämnda och den här boken är, att Hauge försöker sig på en systematisk approach, inte en samlande, kulturhistorisk syn.

Bokens struktur baserar sig på olika åverkningar av olika rusmedel. Först behandlar Hauge alla lugnande medel som opium och opiater, cannabis, alkohol, kava, sömnmedel och andra lugnande rusmedel, bedövningsmedel och lösningsmedel. Boken är uppdelad i kapitel enligt stoffena eller grupper av stoffena som är nära relaterade till varandra, som behandlas en åt gången. På samma sätt presenterar Hauge olika stimulantias historia (koka och kokain, tobak, kaffe och andra koffeinhaltiga växter, betel, khat och besläktade stoffer, amfetamin och liknande stoffer) och hallucinogener (växter och rena hallucinogena stoffer).

Boken har ett omfattande urval av rusmedel: jag saknar ingen speciell sort eller grupp. Även om kapitlen rörande enskilda stoffer är korta och kompakta, redogör författaren såväl för stoffernas kemiska sammansättningar som utföranden, hur stoffet blev "upptäckt", användning och hur det kan variera mellan kön eller samhällsklass, effekter, ofta även skildringar om "hur det känns", möjliga skadeverkningar för individer och åtminstone några huvudlinjer när det gäller utveckling av lagstiftningen gällande olika stoffer i olika länder.

Olika rusmedel ges ungefär lika stort utrymme i boken om man räknar sidorna: Hauge lyfter inte fram inte de "tre stora": kaffe, alkohol och tobak, som är jordens världens mest använda droger (Courtwright 2003, 31). Jag tycker att en liten smula "partiskhet" skulle ha varit berättigad här.

Hauge försöker även att vara neutral. Han undviker att moralisera eller att lyfta fram personliga uppfattningar om rusmedel, rusmedelpolitik eller rusmedellagstiftning.

Han varken fördömer eller godkänner den historiska utvecklingen. Neutralitet är ofta bra, men kanske det är just detta som gör denna bok lite "torr".

Några kapitel är dock intresseväckande och inte alls tråkiga. Ett av de bästa var kapitlet som handlade opium. Där har Hauge kommit åt ganska ny, intressant litteratur.

En detalj som jag var speciellt intresserad av var att enligt Dikötter, Laanan och Xun (2004) var s.k. opiumhålor i Kina före ankomst av européerna knappast sådana fördärvliga nästena, källor till undernäring, fattigdom och sjukdom, som vanligtvis har hävdats i europeiska skildringar. I stället var de av stor betydelse som natthärbärgen för fattigt, hemlöst folk - på sätt och vis dåtidens socialtjänst.

Även opiumhålorna för överklassen var trivsamma och rena. När man läser om historierna av olika "icke-västerländska" rusmedel d.v.s. rusmedel som inte var vitt utbredda i västländerna, kan man konstatera, att västerländska ögon ofta har sett "urfolkens" användning av dessa farligare som än de kanske har varit. 
Bokens ansats är global men samtidigt mycket norsk. I vissa sammanhang framstår Norge som den enda representanten av alla europeiska länder eller rent av alla västländerna. I synnerhet som boken som har skrivits på norska, är det här nödvändigtvis ingen nackdel.

Bokens struktur medför att viktiga gemensamma huvudlinjer i den historiska utvecklingen av rus och rusmedel - som dyker nog upp när man läser om enskilda stoffer - inte klart pekas ut. Boken saknar en helhetssyn.

"Rus och rusmidler gjennom tidene" har ändå två mer allmänna kapitel, som avviker struktur som grundar sig till olika stoffer. I inledning tar författaren reda på "normativa påverkningar på stoffbruk", det vill säga förhållanden som religiösa, sociala och juridiska normer, som varierar i tid och mellan olika kulturer.

De två sistnämnda behandlas mycket kort, men klargörande av religiösa normer är ytterst intressanta.

Förståelsen för religiösa normer är nödvändig för alla som vill förstå olika hållningar till rusmedel och normerna som är rådande i olika delar av världen. Jag bara undrar, varför författaren har lämnat kristendom utanför denna granskning.

Den är ändå världens största religion och det finns dock 165 omnämnande av vin i bibeln (Courtwright 2003, 20)! Hauge koncentrerar sig på de religioner, som ordnade enligt medlemsantal har andra, tredje och fjärde plats: islam, hinduismen och buddhismen.

Olika normer inom olika inriktningar av kristendomen har haft en stark inverkan i synnerhet på attityder till alkohol och alkohollagstiftning.

Jag tänker exempelvis på väckelserörelser ochprotestantiska frikyrkliga rörelser som hade stort inflytande på tillkomsten av nykterhetsrörelserna särskilt i de nordiska länderna och i USA under 1800-talet (se t.ex. Epstein 1981; Johansson 1992; Sulkunen 1987 och 1990; Tyrrell 1991). Nykterhetsrörelserna hade stor påverkan på den ytterst restriktiva alkohollagstiftningensom i andra halvet av 1800-talet och $\mathrm{i}$ början av 1900-talet rådde i de "norra" nordiska länderna (Norge, Sverige, Finland och Island) och i USA. Det är nykterhetsrörelsens arv, att vi i Finland, Norge, Sverige och Island fortfarande framhärdar i våra alkoholmonopoler.

Det andra kapitlet som försöker att ge ett mer omfattande perspektiv på den historiska utvecklingen av ruskulturen handlar om inflytandet av ungdomskulturens födelse och framväxt. I detta kapitel i slutet av boken förklarar Hauge smidigt och sakkunnigt den process, som ledde till att drogerna blev ett globalt fenomen.

Enligt Hauge, var, ända till mitten av 1900-talet, användningen av psykoaktiva stoffer för rekreation mest begränsad till de stoffer som var i traditionellt bruk i enstaka länder. Med undantag av några stoffer, var bruk av narkotiska stoffer begränsat till bruk a läkemedel. Ungdom använde i regel samma stoffer som vuxna. Från 1960-talet skedde en radikal ändring. Rekreationsmässigt bruk av nya stoffer, 
även narkotiska, spred sig bland ungdomen, särskilt i den industrialiserade delen av världen. Den här utvecklingen möjliggjordes av tillkomst av en ny, medelklass ungdom, som hade både tid och pengar. Ny konsumtionskultur föddes och spreds med hjälp av massmedier. Hauge redovisar även vad som försökts att göra för att lösa drogproblemet.

Han börjar med straff, lagstiftning och slutar med olika vårdpraxis och sprutbyte. När Hauge skriver om droger, är han tydligt inom det område som han känner bäst. De traditionella västländska rusmedel, kaffe, alkohol och tobak är uppenbart inte så mycket i hans fokus.

En bok för de breda lagren är den här boken inte. Boken är inte illustrerad, vilket är synd. Den har inte ens en begriplig pärmbild. Det skulle ha varit så mycket enklare att till exempel beskriva vilka delar av cannabis sativa som används om man bara hade en bild. Hauge är inte heller någon popularisator som författare. Men bokens struktur, att vart och ett rusmedel eller rusmedelgrupp får sitt eget kapitel, gör den till ett väl passande uppslagsverk för de som vill få kort, systematisk och neutral information om historia av vissa rusmedel.

Aija Kaartinen, Pol. mag.

Forskare vid Helsingfors Universitet

Referenser:

Courtwright, David: Vanans makt. Drogernas historia och den moderna världens födelse. Historiska Media, Lund 2003.

Dikötter, Frank; Laamann, Lars; Xun, Zhou: Narcotic Culture: A History of Drugs in China. University of Chicago Press USA 2004.

Epstein, Barbara Leslie: The Politics of Domesticity. Women, Evangelism and Temperance in Nineteeth-Century America. Wesleyan University Press, Middletown, Connecticut, USA 1981.

Johansson, Lennart: Brännvin, postillor och röda fanor: om folkrörelser, politik och gammalkyrklihet i sekelskiftets Växsjö. Högskolan i Växjö, 1992.

Schivelbusch, Wolfgang: Paradiset, smaken och förnuftet: njutningsmedlens historia. Alba Stockholm 1982.

Sulkunen, Irma: History of the Finnish Temperance Movement. Temperance as a Civic Religion. Edwin Mellen Press, NY 1990.

Sulkunen; Irma: Kvinnans rösträtt och medborgarorganisering. Historisk tidskrift för Finland 72 (1987):3, 505-521.

Tyrrell, Ian: Women's World Woman's Empire. The Woman's Christian Temperance Union in International Perspective 1880-1930. The University of North Carolina Press. Chapel Hill, USA 1991. 
Rob White (red): Global Environmental Harm. Criminological perspectives. Willan publishing, 2010.

Rob White er en av de mest produktive og ledende forskerne innen økologisk-global kriminologi. Global Environmental Harm er en antologi med tolv bidragsytere fra ulike deler av verden: Nederland, USA, Australia, Sør Afrika, Canada, Kina, Storbritania og Japan. Bidragsyterne dekker ikke bare ulike tema og perspektiv innen feltet global miljøskade, men presenterer også empiriske studier av miljøskade fra ulike deler av verden. Slik får White presentert den store bredden som finnes innen denne delen av kriminologi. De ulike lokale og regionale studiene bindes sammen med et kritisk globalt og transnasjonalt perspektiv. White uttrykker klart målet med boka: Global oppvarming og miljøskader er det vesentligste tema i vår tid, og kriminologiske perspektiv presentert i boka bidrar til å avdekke kompleksiteten og ulike sider ved miljøskade og dets sosiale konsekvenser, og ikke minst, et ønske om å presse fram endringer. Tiden for handling er nå, sier han.

Boka er tredelt. Den første delen - Global Problems - angir trekk ved global miljøskade og hvordan det kan forståes. Rob White sitt bidrag - Globalisation and environmental harm - er plassert i denne delen. Her understreker han betydningen av å utvikle en økologisk-global (ecoglobal) kriminologi, og han setter også fram en dagsorden for studier av miljøskade. I sine tidligere bøker diskuterer White ulike teoretiske perspektiv og begrepsbruk innen ecoglobal criminology. Hans bidrag i denne boken er mindre analytisk og teoretisk - mer konkret, oversiktspreget og handlingsorientert - bl.a. med en oversikt over det han kaller skadens geografi (geographies of harm). Men jeg oppfatter hans bidrag her som en måte å stimulere til engasjement, handling og mer kriminologisk forskning på feltet. Han etterlyser bl. a. mer forskning om eksisterende og potensielle sosiale konflikter klimaendring skaper, og gir en liste over tema relatert til klimaendring spesielt relevante for kriminologisk forskning: ulike typer konflikter som for eks. kampen om miljøressurser og utnytting av ressurser, migrasjon som følge av klimaendring og miljøødeleggelser, konflikter i forbindelse med grenseoverskridende forurensning. Et annet tema han framhever som viktig for kriminologisk forskning er spørsmålet om kriminalisering og regulering av karbon-utslipp.

Den andre delen -Specific issues - gir konkrete case studier av miljøskade. Bredden er stor i empiriske eksempler og illustrerer slik hvordan miljøet ødelegges på ulike måter: avskoging i Sør-Amerika og Asia, frakting av giftig materiale rundt om på kloden, tjæresandprosjektet i Canada som oppfattes som eksempel på statlig-korporativ miljøkriminalitet, ulovlig handel med reptiler i Sør Afrika defineres som conservation crime, illegal handel med utrydningstruede arter, eksempel på forurensning i Kina og i Spania.

Den tredje delen - Alternative visions - diskuterer ulike alternative perspektiv 
på hva kriminologer kan befatte seg med av miljøskade, legale skader så vel som illegale skader. Avi Brisman må nevnes spesielt her. Han tar opp handlinger som er miljøvennlige, men likevel kriminalisert, som for eks. ulovlig fjerning og utnytting av søppel.

Boka avsluttes med et kapittel av Nigel South - The ecocidal tendencies of late modernity: transnational crime, soscial exclusion, victims and rights - der han oppsummerer historien til det han kaller green criminology. South holder fast på det noe uklare begrepet grønn, både om feltet, også om tema: green issues, og om kriminaliteten: green crimes. Jeg liker bedre begreper Rob White har introdusert: ecoglobal criminology og crime against nature. Begrepsbruken i boken variere mellom ulike bidragsytere og samme begrep brukes om både legal og illegal skade. Kanskje det kan være en fordel med mer presis begrepsbruk; i alle fall kan det være et kriminologisk poeng å lage et begrepsmessig skille mellom legal og illegal skade, for eks. mellom skade som rettslig kategori og skade som moralsk kategori. South bruker også et langt sterkere begrep enn grønn skade, nemlig ecocide, og benytter definisjonen til Penguin ordbok fra 2007: "The destruction of the natural environment to the extent that it is unable to support life" (s. 230). Han drøfter senmoderne tendenser som leder mot det han definerer som ecocidal behaviour. Aktiviteter som kan føre til økologisk drap han nevner er bl. a. nedhogging av skog med gamle trær i Tasmania - en prosess som innebærer nedbrenning av landarealer, bruk av giftstoffer i vannkilder og forurensing av atmosfæren - alt dette for å forsyne transnasjonal handel med tømmer til papirindustri og andre industriprodukter i Asia.

Forskning om miljøødeleggelser, dets konsekvenser for samfunn, mennesker og dyr, også samfunnets utnytting av dyr, må nødvendigvis være tverrfaglig. Det framheves også av South; også at faget kriminologi historisk er utviklet fra impulser og kunnskap fra andre fag. Tema innen dette feltet av kriminologien benytter perspektiver fra bl. a. filosofi, statsvitenskap, økonomi og miljøvitenskap (environmental science). Forskningsfeltet kan ses som en møteplass mellom samfunnsvitenskap, humaniora og naturvitenskap. For å si det med South: "Environmental issues provide criminology with perfect site for engagement in interdisciplinary research on local and global issues" (228). Kanskje det er i dette brede tverrfaglige spennet økologisk-global kriminologi kan tilføre andre deler av kriminologien ny kunnskap og perspektiv.

Bokens styrke er kombinasjonen av empiriske studier og teoretiske perspektiver, i tillegg til den store bredden i empiriske studier, både tematisk og geografisk. Rob White har et aktivismeperspektiv i mange av sine tekster som jeg har stor sans for, og som føyer seg til en gammel tradisjon i kriminologi med aksjonsforskning: dannelsen av- og arbeidet i kriminalpolitiske foreninger i Norden med krav om 
fengselsreformer og som også har vært grunnlag for forskning, bl. a. hos Thomas Mathiesen.

Det som gjør dette tverrfaglige feltet til et kriminologisk tema, slik Nigel South utlegger det, er feltets feste på velkjent kriminologisk grunn med tema som bl.a. transnasjonal kriminalitet, sosial ekskludering, offer og rettigheter. At økologisk-globale forskningstema tilhører faget kriminologi skulle det var unødvendig å til stadighet måtte argumentere for. Feltet er godt forankret i kriminologisk forskningstradisjon både teoretisk og tematisk med studier om lovbrudd/overgrep, hvem som rammes og hvorfor, hvilke skader som defineres som kriminalitet og hvorfor andre typer skader forblir legale, også studier av ulike typer kontrollregimer. Det kritiske globale perspektiv har også lenge vært del av annen kriminologisk forskning. Forskjellen, slik jeg ser det, er at kriminologien tidligere har befattet seg med relasjonen mennesket-samfunn, mens økologisk-global kriminologi utvider feltet til relasjonen samfunn-natur der også ikke-humane dyr inngår i relasjonen. Men det som binder sammen ulike forskningsfelt innen kriminologi er bl. a. teori og analyser av maktforhold, hvordan maktutøvelse påfører skader legale som illegale - og skaders konsekvenser.

\section{Guri Larsen}

Institutt for kriminologi og rettssosiologi, Universitetet i Oslo

Yvonne Jewkes \& Majid Yar (eds.): Handbook of Internet Crime. Willan Publishing 2010. (654 s.)

The Handbook of Internet Crime er den indtil dato mest ambitiøse bog af internetkriminalitet indtil videre ifølge redaktørerne Jewkes \& Yar (s. 6). Nu har jeg ikke overblik over alle håndbøger vedrørende internetkriminalitet, men bogen spænder i hvert fald bredt. Håndbogen er delt op i fire dele:

1. Historier og kontekster

2. Former for internetkriminalitet

3. Internetlovgivning og regulering

4. 'Policing' internettet

Der er i alt 30 forfattere, der har bidraget til bogen. Langt de fleste arbejder ved universiteter i UK, men der er også enkelte forskere fra US, Australien, Holland og Belgien, der står for et kapitel i bogen. Yvonne Jewkes er kriminologiprofessor ved Leicester Universitet, mens Majid Yar er sociologiprofessor ved universitetet i Hull.

Kapitlerne (syv i alt) i den første del af bogen handler om mange grundlæggende spørgsmål i forbindelse med start og udvikling af internet og hvordan, den virtuelle verden anvendes til illegale aktiviteter og adfærd. Der behandles spørgs- 
mål som: "hvordan er internet opstået", "hvem begår internetkriminalitet", "er internet befriende eller begrænsende", "hvilke sammenhæng er der mellem internetkriminalitet, kapitalisme og den økonomiske krise", "har internetkriminalitet en underholdningsværdi" og "hvorfor er kriminologien så langsom med at tage internetkriminalitet til sig"?

Den anden del af håndbogen har som overskrift "former for internetkriminalitet", men det er ikke alle kapitler, der handler om kriminalitet. Således handler kap. 12 om "cyber-protest and civil society: the Internet and action repertoires in social movements". Men de fleste kapitler handler om kriminalitet såsom hacking og spredning af computervira, 'intellectual property'-krænkelser, identitetstyveri, bedrageri og børnepornografi. Der er også fokus på internets rolle ved terrorisme. Til sidst er der et kapitel med titlen "harm, suicide and homicide in cyberspace". I dette kapitel ser Maggie Wykes nærmere på spørgsmålet, om internet skal censureres i forhold til chatrooms, opskrifter e.l. i forbindelse med disse fænomener. I et afsnit sui-homicide beskrives Meiwes-sagen (den tyske kannibal som efterspurgte et frivilligt offer på en homoseksuel chatroom). Wykes drager den konklusionen, at det var et enestående tilfælde, som ikke kan tilskrives internettet. I det hele taget er Wykes ikke tilhænger af internetcensur. Hun fremhæver, at der ikke findes overbevisende dokumentation for en kausal forbindelse mellem internet og vold, selvmord og mord. Tværtimod. Hun peger på, at selvmordraten i US er lavere i 2003 i forhold til 1980 - perioden hvori internettet er stormet frem.

Del tre handler om dominerende temaer inden for lovgivningen vedrørende internetkriminalitet. Her tager bogen afsæt i UK og US. UK's Computer Misuse Act fra 1990 er i lovgivningsmæssig forstand en milepæl, og der er fokus på konsekvenserne af den kontroversielle Terrorism Act fra 2000. I US var lovgiveren lidt hurtigere på banen. Den oprindelige lov fra 1984 blev revideret i 1986 til The Computer Fraud and Abuse Act, som løbende er opdateret. I forhold til identitetstyveri er der indført The Identity Theft Enforcement and Restitution Act i 2008. Der findes en stribe særlove for forskellige former for internetkriminalitet i US. Lidt tættere ved Skandinavien er transnationale lovgivning. I bogen diskuteres initiativer af OECD, EU og Council of Europe.

Den sidste, fjerde, del af håndbogen er reserveret bidrag om 'policing' internettet. Der findes ikke en god oversættelse af begrebet 'policing', men det drejer sig om overvågning, efterforskning og regulering af internettet. Der er fokus på både statslige aktører (politi) og private spillere. Er politi klædt på at tage sig af internetkriminalitet? Hvorfor er en del af politiets initiativer mislykkede? Hvilke private aktører findes der og så videre. Internet giver også anledning til nye ord. Således har Matthew Williams skrevet en bidrag om virtuel nabohjælp, og han bruger ordet 'netizens' til at henvise til 'citizens' på nettet. 
Jeg har læst det meste af håndbogen diagonalt og enkelte kapitler nærmere. Bogen virker solid og favner bredt. Selvom man sandsynligvis ikke er interesseret i alle bidrag, opfylder bogen helt sikkert et formål som håndbog og kan bestemt anbefales til alle, der har en interesse i (en aspekt af) internetkriminalitet.

\section{Peter Kruize}

Københavns Universitet

Kathrine Beckett og Steve Herbert: Banished. The New Social Control in Urban America. Oxford University Press, 2010. (207 s.)

I år 2000 var jeg i San Francisco på kriminologikonferanse. Jeg husker ikke så mye fra konferansen, men uteliggerne, de psykisk syke og tiggerne husker jeg godt fra byen som ellers fremstår som hjemsted for de rike og berømte. Kontrastene mellom synlig fattigdom og overflod var slående. I dag ser gate og parkbildet muligens noe annerledes ut, men prisen som er betalt for "opprensingen" $i$ bybildet bør en stille spørsmål ved.

Beckett og Herbert har, med utgangspunkt i Seattle, skrevet en bok om de "nye" teknikkene som brukes for å rydde byene for personer som av ulike grunner oppfattes som brysomme. Boken "Banished. The New Social Control in Urban America." forteller historien bak reintroduksjonen i bruken av forvisninger og ulike tiltak (forordninger) politiet benytter for å begrense personers tilgang til ulike områder. Beckett og Herbert beskriver hvordan løsgjengeri og ordensforstyrrelser i løpet av relativ kort tid atter har fătt en sentral plass innen politiets virksomhet $\mathrm{i}$ flere amerikanske storbyer. To av de rettslige påleggene som brukes mest er, med amerikanernes forkjærlighet for akronymer, forkortet til SODA og SOAP. Det står for Stay Out of Drug Areas og Stay Out of Areas of Prostitution og benyttes av retten som vilkår ved pågripelser, vanligvis for besittelse av mindre mengder narkotika eller ordensforstyrrelser. Hvis den tiltalte samtykker i vilkårene så fungerer de som alternativ til bøter eller kortere fengselsstraffer. Alternativene virker ved første øynekast som humane og "billige" sanksjoner. En hake ved dem er at de faktisk fungerer på en svært inngripende måte i den enkeltes liv. Den dømte registreres $i$ et dataregister politiet har mobil tilgang til. Ved brudd på påleggene om å holde seg borte fra gitte områder benyttes på en ganske summarisk måte kortere fengsling. Regelverket, som i overveiende grad har et sivilrettslig preg, gir store muligheter for skjønnsutøvelse fra politiets side og de trenger ikke forholde seg til det sett av rettsregler som vanligvis gjelder ved pågripelser.

Denne fleksibiliteten sammen med utstrakt bruk av systemer som raskt kan sjekke personers identitet gjør at sanksjonene fungerer som et finmasket kontrollnett. Politiet, under betydelig press for å "rydde opp" byområder, benytter syste- 
met med stor flid. Opplegget er dessuten så enkelt å benytte at det ofte brukes i stedet for andre mer tungvinte fremgangsmåter overfor "gamle kjenninger".

Så kan man jo hevde at bryter de forviste reglene om å holde seg borte fra gitte områder så kan de skylde seg selv. "Banished" viser at det ikke er så enkelt. Mange av de forviste har få steder de kan gå. De er allerede marginalisert fra det etablerte samfunnet og parkene og offentlige eller private områdene hvor folk samles er blant de få stedene de møter kjente, sover og oppholder seg. Boken viser, gjennom sitt intervjumateriale, at forvisningene blir en hard reaksjon som ytterligere innskrenker de forvistes muligheter til å greie seg. Gata og parkene er for mange deres hjem, flere bryr seg derfor ikke så mye om forvisningene og ender jevnlig $\mathrm{i}$ fengsel.

Hva er så bakgrunnen til utvikingen i bruken av denne type teknikker? Beckett og Herbert viser at flere faktorer spiller inn, men at veksten i bostedsløse og marginaliserte på 80 og 90- tallet betyr mye. Samtidig med at stadig flere falt ned i fattigdom, blant annet på grunn av de-industrialisering, ble antall sosialboliger redusert og offentlig velferd ble privatisert og trappet ned. Samtidig skjedde en oppussing, gentrifisering, av bydeler som ofte hadde blitt oppfattet som slum noe som gjorde at fattige ikke lenger hadde råd til å bo der. Slik økte omfanget av bosteds- og arbeidsløse og de som falt utenfor ble mer synlige $\mathrm{i}$ bybildet.

For næringslivet, særlig de som driver forretningsdrift og turistnæring, ble den synlige fattigdommen truende. Folk sjeneres og føler ubehag ved å se uteliggere, tiggere og prostiturete. Det resulterte, som vi også har sett i Oslo og andre nordiske byer, i et politisk press for å rydde opp. Noe som medførte at politiet ble pålagt denne oppgaven samt at private vaktselskaper fant et nytt marked.

Beckett og Herbert understreker at strafferetten langt på vei har fungert som en brems på utviklingen i retning av å lukke byene. På 1960 og 70- tallet skjedde det en avkriminalisering av løsgjengeri og omstreiferi i mange vestlige land. Dette har nå sneket seg tilbake ved at dagens regelverk i liten grad ligger under strafferetten med dens prosessuelle krav.

Beckett og Herbert påviser kriminologiens betydning for denne utviklingen. For politiet er både nulltoleranse, broken windows og situasjonell kriminalitetsforebygging forlokkende perspektiver. Disse "teoriene" hevder at politiet med relativt enkle midler kan redusere, forflytte eller fjerne ulike problemer. De fungerer dessuten legitimerende for bruk av forsvisning, sperring av områder og lignende opplegg.

Forfatterne har intervjuet de involverte partene. Blant politiske myndigheter og pressgrupper, blant annet forretningsdrivende, framstår de nye tiltakene som en suksess, flere er ganske euforiske i sin beskrivelse av ryddingen av Seattle. Politiet har fått myndighet og mulighet til å gjøre jobben og er fornøyd med at det 
enkelt lar seg gjøre. Det er nærmest automatikk i pågripelsene og forvisningene. For uteliggere, tiggere, narkomane og prostituerte har derimot livet stort sett blitt betydelig verre. Noe av det beste med boka er at den gir de bortviste en stemme. At de som rammes av reguleringsiveren får uttrykke sitt syn er ikke vanlig. Disse forteller oss stort sett ganske triste historier. Noe av det mest overraskende, men det burde det jo ikke være, er at parkene og stedene hvor uteliggerne, tiggerne og andre utstøtte møtes for dem er "deres sted", som et hjem for dem, et sted de møter andre - ofte deres eneste sosiale arena. Når de bortvises medfører det alvorlige konsekvenser. De mister "sitt hjem", sine omgangsvenner, sitt nettverk og marginaliseres ytterligere ved at deres status kriminaliseres.

Har så boken relevans for nordiske forhold? Utvilsomt. Flere studier fra nyere tid har vist hvordan ikke bare politiet, men også private vaktselskaper benytter seg av ulike strategier for å holde uønskede personer borte fra deler av byen. Lomell sin studie av kameraovervåkning i Oslo og Frantzens studie av narkotikakontroll på gateplan i København er to nyere eksempler. Den nye bølge av bortvisninger og ekskludering, med loven $\mathrm{i}$ hånd, $\mathrm{av}$ uønskede marginaliserte deler av befolkningen fra byområder har ennå ikke nådd opp til amerikanske proporsjoner. Men det er nok av eksempler også hjemme fra. Den stadige forflyttningen av personer i tilknytning til den åpne narkotikaomsetningen, hva vi skal gjøre med tiggerne og kampen mot den åpenlyse gateprostitusjonen er eksempler. Diskusjonene rundt reguleringen av dette ligner mye på hva Beckett og Herbert beskriver. Næringslivet, men også beboere, presser på for å fjerne de uønskede og politikere ønsker å "rense byen", ofte med bakgrunn i turistnæringens klager eller beboere som føler seg utygge.

Vi reagerer alle når vi ser menneskelig misere og elendighet på gata. Spørsmålet er hvordan man skal forholde seg til det og hva man faktisk kan og bør gjøre. "Banished" tar opp disse spørsmålene avslutningsvis. De viser at de menneskelige kostnadene ved Seattles måte å løse problemene på er for høye. Hva som for noen fremstår som en suksess har betydelige skadevirkninger på de som lever på gata. "Banished" viser hvordan sosiale problemer med rot i grunnlegende strukturelle og økonomiske forhold omformuleres og behandles som lovbrudd og kriminalitet. Samtidig viser de at problemene ikke kan løses på denne måten. Hvis man skal kunne få til en mer varig og human løsning må man atter adressere dette som grunnleggende sosiale og økonomiske problemer.

Paul Larsson

Politihøgskolen i Oslo 
Philip Lalander: Respekt - Gatukultur, ny etnicitet och droger. Liber, 2009. ISBN 978-91-47-08950-5

Bogen Respekt - Gatukultur, ny etnicitet och droger er en etnografisk skildring af en gruppe unge chilenske mænd i byen Norrköping i det sydøstlige Sverige. Den er skrevet af professor i socialpsykologi ved Växjö Universitet, Philip Lalander, der er forfatter til en række bøger og artikler om ungdomsgrupper og ungdomskultur med fokus på misbrug blandt unge. Omdrejningspunktet i bogen er de unges søgen efter nærhed, tryghed og anerkendelse i et Sverige, der ifølge Lalander er blevet mere og mere segregeret siden 1990'erne, og som tager stærkt afstand fra de unge pga. deres brug og salg af narkotika herunder specielt heroin.

I bogen er det den sociale identitets- og meningssammenhæng knyttet til heroinen, der er i centrum, og dette ud fra følgende fem spørgsmål: 1) Hvordan ser de unge chileneres forhistorie ud? 2) Hvordan opfatter de sig selv? 3) Hvilke typer af sociale netværk og relationer skabes der mellem dem? 4) Hvordan blev de involveret i narkotikasalg og heroin? og 5) Hvordan har deres relationer til det svenske majoritetssamfund set ud, og hvordan forandres relationerne over tid?

Studiet er kvalitativt, og datamaterialet består af interviews og observation, der komplementerer hinanden $\mathrm{i}$ et forsøg på at forstå gruppen af unge chilenere. Der er foretaget rundt 100 interviews med i alt 23 personer heraf 15 unge fra gruppen, tre af deres mødre, tre veninder og to venner. Et egentligt observationsstudium er foretaget i perioden fra 2005-2007, hvor Lalander var bosat i og omkring Hageby i det sydlige Norrköping. I bogen beskriver han sin adgang til feltet, sine positioner (identiteter) og sin tilgang, der er inspireret af Chicagosociologien. Læseren gives i relation hertil et billede af de problemer og konflikter, som er knyttet til hans ageren i feltet og bl.a. omhandler at være vidne til kriminalitet.

Lalander gør brug af Philippe Bourgois forståelse af gadekultur, og han trækker på en række anerkendte sociologer og kulturteoretikere gennem forskellige teoretiske begreber. Han lader sig inspirere af forskning om nye etniciteter og intersektionalitet, idet han beskriver, hvordan de sociale og kulturelle processor hænger sammen med alder, køn, klasse og etnicitet. Det interessante i den forbindelse er, hvordan gruppen af chilenske mænd sammen skaber en anden version af virkeligheden i en gadekultur med sin egen logik og sine egne regler og love. Gadekulturen udspringer af en kollektiv oplevelse af at være udstødt af samfundet, og de unge søger en form for anerkendelse og respekt, som er stærkere end den, samfundet giver dem.

Gadekulturens udtryk skal findes i specielt reggaemusik og gangsta rap, og der er ifølge Lalander skabt en slags gademaskulinitet, som hænger sammen med de unges sociale klasse og forestillinger om etnisk oprindelse. I forhold til gruppen af unge chilenske mænd er det ikke nok at forstå etnicitet i lyset af kulturarv, histo- 
risk kontinuitet og et kulturelt centrum, da de vha. symbolsk kreativitet forsøger at skabe et rum, hvor identiteter kan formes, og disse identiteter er dynamiske og afhængige af situationen. Bogen Respekt - Gatukultur, ny etnicitet och droger er et grundigt og velskrevet studium af en gruppe unge, og den kan derfor anbefales til alle med interesse for kvalitativ forskning samt praktikere og teoretikere, som arbejder med ungdomsgrupper og ungdomskultur.

Maria Libak Pedersen

Justitsministeriets Forskningskontor 